\title{
Faktor Risiko Kejadian Sakit Tuberkulosis pada Anak yang Kontak Serumah dengan Penderita Tuberkulosis Dewasa
}

\author{
Nevita, Retno Sutomo, Rina Triasih \\ Bagian Ilmu kesehatan Anak Fakultas Kedokteran Universitas Gadjah Mada/RSUP Dr Sardjito, \\ Yogyakarta
}

\begin{abstract}
Latar belakang. Anak yang tinggal serumah dengan penderita TB paru dewasa berisiko tinggi untuk terinfeksi dan sakit TB. Pelacakan terhadap anak kontak serumah (contact screening) berpotensi menurunkan morbiditas dan mortalitas TB pada anak. Namun demikian, kegiatan itu belum rutin dilakukan di negaranegara endemis karena keterbatasaan tenaga dan fasilitas.

Tujuan. Mengetahui faktor risiko sakit TB pada anak yang tinggal serumah dengan penderita TB paru dewasa

Metode. Penelitian kasus kontrol pada anak usia $\leq 15$ tahun yang tinggal serumah dengan penderita TB paru dewasa yang diobati di 18 Puskesmas, 2 balai pengobatan paru, dan 3 rumah Sakit di Kotamadya Yogyakarta antara bulan agustus 2010 dan Juni 2012. Kami melakukan anamnesis, pemeriksaan fisik, uji tuberkulin, dan foto Rontgen dada pada semua anak yang memenuhi kriteria inklusi dan eksklusi untuk menentukan ada tidaknya sakit TB. Dikatakan sakit TB apabila terdapat paling sedikit satu gejala TB dan foto Rontgen dada yang sugestif TB atau ditemukannya gejala dan tanda extrapulmonary TB.

Hasil. Terdapat 126 anak, 21 sebagai kasus dan 105 sebagai kontrol. Karakteristik anak (usia balita (OR 1,9495\% CI (0,76-4,93), telah mendapatkan vaksinasi BCG (OR 1,09 95\% CI (0,12-8,83)) karakteristik kasus indeks (derajat BTA sputum positif (OR 2,72 95\% CI (0,76 -9,78), orang tua sebagai kasus indeks (OR 1,05 95\% CI (0,42-2,67)) dan karakteristik lingkungan (polusi asap rokok dalam rumah (OR 1,07 95\% CI (0,38-2,99) dan jumlah anggota keluarga >6 (OR1,85 95\% CI (0,70-4,88) tidak berhubungan dengan risiko terjadinya sakit TB pada anak kontak serumah.

Kesimpulan. Risiko kejadian sakit TB pada anak tersebut tidak berhubungan dengan karakteristik anak, kasus indeks, dan lingkungan yang diteliti. Sari Pediatri 2014;16(1):5-10.
\end{abstract}

Kata kunci: tuberkulosis, kontak serumah, sakit TB, faktor risiko

\footnotetext{
Alamat korespondensi:

Dr. Retno Sutomo, SpA , Ph.D. RSUP Dr. Sardjito. Jl. Kesehatan No.

1, Yogyakarta. Telp. +62274-587333, 561616, Fax: +62274-583745.

E-mail:rsutomo@idai.or.id,nvtb2008@idai.or.id
}

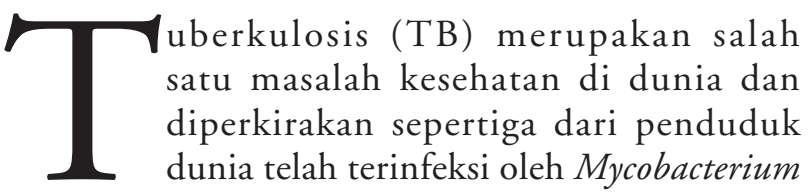


tuberculosis. Insiden TB di dunia pada tahun 2011 diperkirakan 8.7 juta, setara dengan 125 kasus pada setiap 100.000 populasi, dengan prevalensi TB sekitar 12 juta kasus 0,5 juta kasus (6\%). ${ }^{1}$ Angka kematian penderita TB di dunia sekitar 1,4 juta kasus. Secara global, angka kematian TB telah menurun $41 \%$ sejak tahun 1990 (World Health Organization 2012). Namun demikian, saat ini TB masih merupakan penyakit infeksi kedua terbanyak yang menyebabkan kematian setelah infeksi Human Immunodeficiency Virus (HIV). ${ }^{1}$

Saat ini, program pengendalian TB dilakukan berdasarkan tiga strategi berikut, 1. menemukan dan mengobati kasus TB dewasa, 2. pengobatan infeksi laten TB, dan 3. vaksinasi BCG. Pengobatan infeksi laten TB belum banyak diimplementasikan, sedangkan vaksinasi BCG hanya efektif untuk mencegah penyakit TB berat, seperti TB miliar dan meningitis TB. ${ }^{2}$

Strategi penemuan kasus saat ini dilakukan secara pasif (passive case finding). Case detection rate (CDR) merupakan salah satu indikator untuk menilai keberhasilan program TB. Selama ini, secara global, CDR yang dicapai masih di bawah target yang ditentukan yaitu di atas $70 \% .{ }^{3}$ Case detection rate yang rendah mengindikasikan bahwa kasus $\mathrm{TB}$ di masyarakat masih belum dapat diidentifikasi dan diterapi dengan adekuat dan penularan penyakit TB masih terus berlangsung. ${ }^{4}$

Pada anak yang kontak erat atau tinggal serumah dengan penderita $\mathrm{TB}$ dewasa, risiko penularan penyakit TB meningkat, terutama yang berusia $<5$ tahun (balita) atau dalam kondisi imunokompromais, ${ }^{5}$ kondisi tempat tinggal yang padat, derajat keparahan dari sumber kasus yang ditentukan hasil pemeriksaan batang tahan asam (BTA) positif dari sputum penderita, kelainan pada paru yang ditunjukkan secara radiologis. ${ }^{6,7}$

Pada anak yang kontak serumah dengan penderita TB dewasa, pelacakan dan manajemen mempunyai potensi yang besar untuk menurunkan kasus TB sehubungan dengan morbiditas dan mortalitas pada anak..$^{8-10,10}$ Meskipun demikian, sampai saat ini ,kegiatan tersebut belum rutin dilakukan di negaranegara endemis TB. Salah satu penyebab permasalahan ini adalah keterbatasan fasilitas dan tenaga kesehatan di negara berkembang. Oleh karena itu, perlu dicari pemecahan masalah ini. Salah satunya dengan melakukan kegiatan pelacakan kontak pada anak yang berisiko menjadi sakit TB.

\section{Metode}

Dilakukan penelitian kasus kontrol pada anak usia $\leq$ 15 tahun yang tinggal serumah dengan penderita TB paru dewasa yang diobati di 18 Puskesmas, 2 balai pengobatan paru, dan 3 rumah Sakit di Kotamadya Yogyakarta antara bulan Agustus 2010 dan Juni 2012. Penelitian dilakukan setelah mendapat persetujuan dari komite etik. Dilakukan anamnesis, pemeriksaan fisik, uji tuberkulin, dan foto Rontgen dada pada semua anak yang memenuhi kriteria inklusi untuk menentukan ada tidaknya sakit TB. Dikatakan sakit TB apabila terdapat paling sedikit satu gejala TB dan foto Rontgen dada yang sugestif TB atau ditemukannya gejala dan tanda extrapulmonary TB. Anamnesis dilakukan oleh peneliti untuk mendapatkan data demografi dan untuk mengetahui adanya gejala TB.

Data diolah dengan menggunakan SPPS 17. Perbedaan proporsi antara dua kelompok dianalisis dengan uji chi square $\left(X^{2}\right)$. Analisis antara variabel akan dilihat dengan analisis univariat. Variabel yang menunjukkan nilai kemaknaan $<0,05$ akan dilanjutkan pada analisis multivariat, dengan menggunakan analisis logistik regresi.

\section{Hasil}

Selama periode penelitian, didapatkan 21 anak kontak serumah dengan penderita TB dewasa yang didiagnosis sakit TB. Sejumlah 105 anak kontak serumah yang tidak sakit TB dimasukkan sebagai kontrol. Karakteristik kedua kelompok tersebut tertera pada Tabel 1 .

Secara umum, sebagian besar karakteristik kelompok kasus dan kelompok kontrol tidak berbeda, tetapi proporsi jenis kelamin anak laki-laki pada kelompok kontrol (56\%) lebih tinggi daripada kelompok kasus $(42,9 \%)$ dengan rata rata usia pada kelompok kasus adalah 72,8 bulan $(+$ SD 55,3$)$ dan kelompok kontrol 82,0 bulan (+SD 56,2). Proporsi usia balita pada kelompok kasus lebih tinggi $(57,1 \%)$ dibanding pada kelompok kontrol (40,8\%). Hampir semua anak pada kelompok kasus dan kelompok kontrol telah mendapatkan vaksinasi BCG $(95,2 \%)$, tetapi skar BCG lebih banyak pada kelompok kasus (95,2\%) dibandingkan dengan kelompok kontrol (76\%). Proporsi anak yang tidur sekamar dengan kasus indeks lebih banyak pada kelompok kasus $(52,4 \%)$ dibandingkan dengan kelompok kontrol $(43,2 \%)$. 
Tabel 1. Karakteristik anak, kasus indeks, dan lingkungan

\begin{tabular}{|c|c|c|}
\hline Karakteristik & $\begin{array}{c}\text { Kelompok kasus } \\
\mathrm{n}=21\end{array}$ & $\begin{array}{l}\text { Kelompok kontrol } \\
\mathrm{n}=105\end{array}$ \\
\hline $\begin{array}{l}\text { Karakteristik anak } \\
\text { Jenis kelamin laki-laki (\%) }\end{array}$ & $9(42,9)$ & $70(56,0)$ \\
\hline Usia, bulan, rerata & $72,8+\operatorname{SD} 55,3$ & $82,0+\operatorname{SD} 56,2$ \\
\hline Balita (\%) & $12(57,1)$ & $55(44)$ \\
\hline Imunisasi BCG (\%) & $20(95,2)$ & $119(95.2)$ \\
\hline Ada skar BCG (\%) & $20(95,2)$ & $95(76)$ \\
\hline Tidur sekamar (\%) & $11(52,4)$ & $54(43,2)$ \\
\hline $\begin{array}{l}\text { Karakteristik kasus indeks } \\
\text { Jenis kelamin laki-laki (\%) }\end{array}$ & $12(57,1)$ & $77(61,6)$ \\
\hline Hubungan keluarga & & \\
\hline $\begin{array}{l}\text { Ibu (\%) } \\
\text { Ayah (\%) } \\
\text { Kakek/nenek (\%) } \\
\text { Lain-lain (\%) }\end{array}$ & $\begin{array}{l}6(28,6) \\
6(28,6) \\
3(14,3) \\
6(28,6)\end{array}$ & $\begin{array}{l}23(18,4) \\
47(37,6) \\
26(20,8) \\
29(23,2)\end{array}$ \\
\hline BTA kasus indeks & & \\
\hline $\begin{array}{l}\text { Negatif (\%) } \\
\text { Positif } 1(\%) \\
\text { Positif } 2(\%) \\
\text { Positif } 3(\%)\end{array}$ & $\begin{array}{l}3(14,3) \\
7(33,3) \\
3(14,3) \\
8(38,1)\end{array}$ & $\begin{array}{l}39(31,2) \\
34(27,2) \\
17(13,6) \\
35(28,0)\end{array}$ \\
\hline $\begin{array}{l}\text { Karakteristik lingkungan } \\
\text { Polusi rokok (\%) } \\
\text { Jumlah penghuni rumah (rerata, IQ range) }\end{array}$ & $\begin{array}{c}6(28,6) \\
5,86+\text { SD } 2,27\end{array}$ & $34(27,2)$ \\
\hline
\end{tabular}

Tabel 2. Hasil analisis faktor risiko sakit TB

\begin{tabular}{lcc}
\hline Faktor risiko & OR (IK 95\%) & P \\
\hline Usia balita & $1,94(0,76-4,93)$ & 0,23 \\
Status imunisasi BCG & $1,09(0,12-8,83)$ & 0,74 \\
Orang tua sebagai kasus indeks & $1,05(0,41-2,67)$ & 0,92 \\
Polusi rokok dalam rumah & $1,07(0,38-2,99)$ & 0,90 \\
Kasus indeks dengan BTA + & $2,72(0,76-9,78)$ & 0,11 \\
Jumlah anggota keluarga $>6$ & $1,85(0,70-4,88)$ & 0,21 \\
\hline
\end{tabular}

Dari karakteristik kasus indeks, proporsi jenis kelamin laki-laki lebih banyak pada kelompok kontrol $(61,1 \%)$ dibandingkan kelompok kasus $(57,1 \%)$. Sebagian besar kasus indeks merupakan orang tua (ayah dan ibu) baik pada kelompok kasus maupun pada kelompok kontrol. Sputum BTA kasus indeks pada kelompok kasus sebagian besar adalah dengan hasil positif $3(38,1 \%)$, sedangkan pada kelompok kontrol sebagian besar dengan BTA negatif. Karakteristik lingkungan yang dilihat adalah polusi asap rokok di dalam rumah, pada kelompok kasus dan kontrol tidak jauh berbeda yaitu 28,6\% dan $27,2 \%$. Rata-rata jumlah penghuni rumah baik pada kelompok kasus dan kelompok kontrol sama, yaitu 6 (66,7\% dan 52\%). Semua anak yang sakit TB menunjukkan respon yang baik dengan pemberian terapi anti TB. Satu anak didiagnosis sebagai meningitis TB yang datang dengan keluhan demam lama dan kejang, didukung dengan gambaran milier pada foto Rontgen dada.

Hasil pada Tabel 2 menunjukkan bahwa semua faktor risiko yang diteliti tidak ada yang bermakna. 


\section{Pembahasan}

Penelitian ini tidak dapat menunjukkan karakteristik anak, kasus indeks, dan lingkungan yang berhubungan dengan risiko terjadinya sakit TB di antara anak-anak yang kontak erat dengan penderita TB paru dewasa. Beberapa penelitian menyebutkan bahwa risiko sakit TB pada anak terutama berhubungan dengan perbedaan kerentanan gen tertentu terhadap kuman TB. ${ }^{11}$ Penelitian Gessner $\mathrm{dkk}^{12}$ menemukan variasi dari alel natural resistence-associated macrophage protein gene1 (NRAMP1) berhubungan dengan sakit TB pada anak. Penelitian ini tidak melihat hubungan antara gen tertentu dengan faktor risiko kejadian sakit TB karena keterbatasan biaya.

Penelitian sebelumnya yang mengevaluasi faktor risiko sakit TB di antara anak-anak yang kontak dengan penderita TB dewasa hanya sedikit. ${ }^{7,11,13,14}$ Di antara penelitian tersebut hanya satu penelitian yang diadakan di Alaska yang mengidentifikasi umur anak yang muda hasil BTA positif dan adanya lesi di lobus kiri atas paru pada foto Rontgen dada kasus indeks, serta orang tua sebagai kasus indeks sebagai faktor risiko sakit TB. ${ }^{11}$

Usia muda merupakan faktor risiko sakit untuk seorang anak yang kontak serumah dengan penderita TB dewasa dikarenakan imunitas selularnya yang belum berkembang sempurna. Namun demikian, beberapa penelitian menunjukkan hasil yang berbeda ${ }^{7,13,14}$ Penelitian di Afrika Selatan ${ }^{14}$ ditunjukkan bahwa risiko anak yang tinggal serumah dengan penderita dewasa tidak berhubungan dengan faktor usia, risiko sakit tidak meningkat di usia kurang atau lebih dari 6 bulan, kurang atau lebih dari 12 bulan atau lebih dari 24 bulan. Walaupun begitu, penelitian ini menunjukkan bahwa adanya kecenderungan anak usia balita untuk menjadi sakit lebih tinggi dibandingkan dengan usia yang lebih tua dan anak dengan usia di bawah 2 tahun mempunyai kecenderungan untuk menjadi sakit dengan kelainan saluran pernafasan yang lebih serius. Hasil serupa juga didapatkan pada penelitian di Filipina ${ }^{13}$ dan di Malawi. ${ }^{7}$ Pada penelitian di Malawi ${ }^{7}$ juga ditunjukkan hasil yang tidak bermakna, dan kelemahan pada penelitian itu adalah jumlah sampel yang relatif kecil sehingga tidak dapat melihat adanya perbedaan dan berbasis rumah sakit sehingga tidak mencerminkan populasi yang sesungguhnya. Hasil penelitian kami juga menunjukkan bahwa risiko terjadinya sakit TB pada anak sama dengan anak yang lebih tua. Hal tersebut kemungkinan karena status imunitas kedua kelompok umur tidak berbeda. Secara klinis, semua anak pada penelitian tidak ditunjukkan adanya kondisi immunocompromise.

Di daerah endemis $T B$, vaksinasi BCG secara rutin diberikan kepada semua anak pada masa neonatus. Penelitian telah membuktikan bahwa BCG terutama memberikan perlindungan terhadap terjadinya TB berat seperti TB miliar, meningitis $\mathrm{TB}$, dan spondilitis $\mathrm{TB}$, dengan tingkat perlindungan yang bervariasi antara 0-80\%. ${ }^{2}$ Namun demikian, vaksinasi BCG sangat sedikit atau hampir tidak memberikan perlindungan terhadap bentuk TB yang lain, seperti TB paru. ${ }^{15}$

Pada penelitian ini, hampir semua anak telah mendapat imunisasi BCG. Penelitian ini memberikan hasil bahwa status imunisasi BCG yang dibuktikan dengan adanya skar tidak berhubungan dengan kejadian sakit TB pada anak. Hasil serupa juga didapatkan pada penelitian di Filipina, ${ }^{13}$ demikian juga penelitian di Malawi ${ }^{7}$ menunjukkan hasil yang tidak bermakna.

Faktor risiko yang dilihat dari kasus indeks adalah hubungan keluarga antara kasus indeks dengan anak yang tinggal serumah. Sebagian besar kasus indeks pada penelitian ini adalah orang tua dari anak tersebut, tidak ada perbedaan antara ayah dan ibu sebagai kasus indeks pada kelompok kasus (28,6\%), sedangkan pada kelompok kontrol ayah lebih banyak sebagai kasus indeks (37,6\%). Pada penelitian ini, orang tua sebagai kasus indeks tidak mempunyai hubungan dengan risiko sakit TB pada anak yang tinggal serumah. Hasil yang sama juga didapatkan pada penelitian di Filipina. ${ }^{13}$ Hasil yang berbeda didapatkan pada penelitian di Alaska ${ }^{11}$ bahwa orang tua sebagai kasus indeks merupakan faktor risiko untuk menjadi sakit, tetapi adanya faktor risiko ini dianalisis dengan adanya kesamaan genetik antara orang tua dengan anak.

Pada penelitian ini, 85,7\% kasus indeks kelompok kasus mempunyai hasil BTA positif. Hasil penelitian kami dan penelitian sebelumnya menunjukkan bahwa derajat keparahan sakit kasus indeks yang ditentukan berdasarkan derajat kepositifan sputum BTA bukan risiko terjadinya sakit pada anak yang kontak dengan penderita TB dewasa. Anak yang kontak erat dengan penderita TB paru dengan BTA positif tidak mempunyai risiko lebih tinggi untuk sakit TB dibandingkan dengan anak-anak yang kontak erat dengan penderita TB paru BTA negatif. Penelitian oleh Beyers dkk ${ }^{14}$ di Afrika Selatan dan penelitian Sinfield $\mathrm{dkk}^{7}$ di Malawi, mendapatkan hasil yang sama. Pada penelitian Gessner $\mathrm{dkk}^{11}$ di Afrika Selatan 
juga didapatkan hasil yang tidak bermakna, pada penelitian ini lebih melihat lokasi kelainan pada paru dibandingkan dengan hasil sputum BTA.

Lingkungan dapat berperan sebagai faktor yang berhubungan dengan kejadian sakit TB. Adanya orang yang merokok di dalam rumah menyebabkan anak menjadi perokok pasif yang dapat menyebabkan daya tahan tubuh menurun, terutama pada saluran pernapasan. Pada penelitian ini, adanya polusi asap rokok (perokok pasif) tidak berhubungan dengan kejadian sakit TB pada anak. Hal ini mungkin disebabkan karena pada kelompok kasus dan kelompok kontrol, sebagian besar orang dewasa tidak merokok ( $71,4 \%$ dan $72,8 \%)$. Data mengenai adanya penghuni rumah yang merokok didapatkan dengan anamnesis sehingga sangat besar terjadi bias, sedangkan penelitian oleh Altet $\mathrm{dkk}^{16}$ menunjukkan hasil yang bermakna.

Kepadatan penghuni rumah adalah banyaknya jumlah orang yang tinggal serumah dengan kasus indeks. Kepadatan penghuni rumah telah lama diduga berpengaruh dengan kejadian TB, tetapi pada penelitian ini kepadatan hunian tidak berpengaruh dengan kejadian TB pada anak. Penelitian di Malawi ${ }^{7}$ juga memberikan hasil yang sama. Kepadatan hunian rumah lebih berhubungan dengan risiko penularan TB bukan risiko terjadinya sakit TB pada anak yang kontak serumah. Secara teori, pada kondisi rumah yang padat, transmisi lebih mudah terjadi karena jarak antara anak dengan kasus indeks menjadi lebih dekat. ${ }^{17}$

Penelitian ini mempunyai beberapa keterbatasan, data foto Rontgen dada kasus indeks untuk menilai derajat keparahan dan lokasi kelainan di paru tidak bisa didapatkan. Hal tersebut dikarenakan diagnosis TB paru dewasa dilakukan berdasarkan hasil pemeriksaan sputum BTA. Foto Rontgen dada tidak dilakukan secara rutin. Penelitian sebelumnya menunjukkan bahwa adanya kavitasi dan lesi pada lobus kiri atas menunjukkan bahwa penyakit sangat infeksius dan merupakan faktor risiko untuk menjadi sakit. Pengambilan data dengan menggunakan kuesioner memungkinkan untuk terjadinya bias.

Penelitian ini tidak berhasil menemukan adanya hubungan antara kejadian sakit TB dengan karakteristik anak (umur balita, status imunisasi BCG) karakteristik kasus indeks (orang tua sebagai penderita TB dewasa, sputum + penderita dewasa), dan karakteristik lingkungan (asap rokok dalam rumah, jumlah anggota keluarga $>6$ ). Dapat dilakukan penelitian multisenter sehingga didapatkan jumlah sampel yang besar untuk melihat faktor risiko sakit pada anak yang kontak serumah dengan penderita TB paru dewasa. Dilakukan penelitian untuk melihat faktor gen pada anak yang sakit TB sehingga dapat diketahui apakah risiko sakit TB pada anak berhubungan dengan kelemahan gen tertentu.

Walaupun tidak didapatkan faktor risiko kejadian sakit pada anak yang kontak serumah dengan penderita TB dewasa, pelacakan kontak TB terhadap anak yang tinggal serumah dengan penderita TB paru dewasa tetap penting dilakukan karena pengobatan secara dini akan mencegah berkembangnya penyakit menjadi lanjut serta dapat memutuskan mata rantai penularan TB.

\section{Daftar pustaka}

1. World Health Organization. Global tuberculosis report. Geneva: Switzerland, WHO;2012.

2. Colditz GA, Berkey CS, Mosteller F, Brewer TF, Wilson ME, Burdick E, dkk. The efficacy of bacillus Calmette-Guerin vaccination of newborns and infants in the prevention of tuberculosis: meta-analyses of the published literature. Pediatrics 1995;96:29-35.

3. World Health Organization. Global tuberculosis control: a short update to the 2009 report. Geneva: Switzerland, WHO; 2009.

4. Triasih R, Rutherford M, Lestari T, Utarini A, Robertson CF, Graham SM. Contact investigation of children exposed to tuberculosis in South East Asia: a systematic review. J Trop Med 2012;2012:301808.

5. Marais BJ, Gie RP, Schaaf HS, Hesseling AC, Obihara CC, Starke JJ, dkk. The natural history of childhood intra-thoracic tuberculosis: a critical review of literature from the pre-chemotherapy era. Int J Tuberc Lung Dis 2004;8:392-402.

6. Kenyon TA, Creek T, Laserson K, Makhoa M, Chimidza N, Mwasekaga M, dkk. Risk factors for transmission of Mycobacterium tuberculosis from HIV-infected tuberculosis patients, Botswana. Int J Tuberc Lung Dis $2002 ; 6: 843-50$.

7. Sinfield R, Nyirenda M, Haves S, Molyneux EM, Graham SM. Risk factors for TB infection and disease in young childhood contacts in Malawi. Ann Trop Paediatr 2006;26:205-13.

8. Marais BJ, Ayles H, Graham SM, Godfrey-Faussett P. Screening and preventive therapy for tuberculosis. Clin Chest Med 2009;30:827-46.

9. Gomes VF, Andersen A, Wejse C, Oliveira I, Vieira FJ, Joaquim LC, dkk. Impact of tuberculosis exposure at 
home on mortality in children under 5 years of age in Guinea-Bissau. Thorax 2011;66:163-7.

10. Zachariah R, Spielmann MP, Harries AD, Gomani P, Graham SM, Bakali E, dkk. Passive versus active tuberculosis case finding and isoniazid preventive therapy among household contacts in a rural district of Malawi. Int J Tuberc Lung Dis 2003;7:1033-9.

11. Gessner BD, Weiss NS, Nolan CM. Risk factors for pediatric tuberculosis infection and disease after household exposure to adult index cases in Alaska. J Pediatr 1998;132:509-13.

12. Malik S, Abel L, Tooker H, Poon A, Simkin L, Girard $\mathrm{M}$, dkk. Alleles of the NRAMP1 gene are risk factors for pediatric tuberculosis disease. Proc Natl Acad Sci U S A 2005;102:12183-8.

13. Salazar-Vergara RM, Sia IG, Tupasi TE, Alcaneses MR, Orillaza RB, Co V, dkk. Tuberculosis infection and disease in children living in households of Filipino patients with tuberculosis: a preliminary report. Int J
Tuberc Lung Dis 2003;7:S494-S500.

14 Beyers N, Gie RP, Schaaf HS, van ZS, Talent JM, Nel $\mathrm{ED}$, dkk. A prospective evaluation of children under the age of 5 years living in the same household as adults with recently diagnosed pulmonary tuberculosis. Int J Tuberc Lung Dis 1997;1:38-43.

15. Trunz BB, Fine P, Dye C. Effect of BCG vaccination on childhood tuberculous meningitis and miliary tuberculosis worldwide: a meta-analysis and assessment of cost-effectiveness. Lancet 2006;367:1173-80.

16. Altet MN, Alcaide J, Plans P, Taberner JL, Salto E, Folguera LI, dkk. Passive smoking and risk of pulmonary tuberculosis in children immediately following infection. A case-control study. Tuber Lung Dis 1996;77:537-44.

17. Rutherford ME, Hill PC, Maharani W, Apriani L, Sampurno H, van CR, dkk. Risk factors for Mycobacterium tuberculosis infection in Indonesian children living with a sputum smear-positive case. Int J Tuberc Lung Dis 2012;16:1594-9. 